\title{
LONG-TERM, SEASONAL AND SHORT-TERM FLUCTUATIONS IN THE WATER LEVEL OF THE SOUTHERN BALTIC SEA
}

\author{
TOMASZ WOLSKI ${ }^{1}$, BERNARD WIŚNIEWSKI ${ }^{2}$ \\ ${ }^{1}$ Faculty of Geosciences, University of Szczecin, Poland \\ ${ }^{2}$ Faculty of Navigation, Maritime University of Szczecin, Poland \\ Manuscript received: February 19, 2014 \\ Revised version: July 29, 2014
}

\begin{abstract}
WolsKi T., WiśnIEWSKI B., 2014. Long-term, seasonal and short-term fluctuations in the water level of the Southern Baltic Sea. Quaestiones Geographicae 33(3), Bogucki Wydawnictwo Naukowe, Poznań, pp. 181-197, 5 tables, 13 figs. DOI 10.2478/quageo-2014-0041, ISSN 0137-477X.

ABSTRACT: Aim of this work are analyses of oscillations sea levels in the Southern Baltic on a scale of short-term changes, seasonal and long-term (age). The study was based on observational data in different periods time for tide gauges station of the Polish coast. On the example of some storm situations presents the part of the baric wave and the wind in the formation of extreme sea levels. The primary cause of the annual variability of sea levels was the characteristics of the annual and semi-annual oscillations (the annual and semi-annual solar tide). In the work also determined the rate of long-term sea-level rise for the Polish coast.
\end{abstract}

KEY wORDS: sea level, storm surge, tide, Southern Baltic Sea

Address of the corresponding author: Tomasz Wolski, Faculty of Geosciences, University of Szczecin, Mickiewicza 16, 70-383

Szczecin, Poland; e-mail: natal@univ.szczecin.pl

\section{Introduction}

Fluctuations of the sea level constitute an important geophysical, oceanographic, and climatologic problem. Sea level fluctuations, by changing the water depth, substantially affect the location of characteristic components of the shore zone, and thus may contribute to the coastal erosion and the landward shift of the shoreline. A considerable part of sedimentological effects on the shore is generated by long-term (on the scale of years or decades) changes in the sea level. It is of utmost importance to monitor the sea level fluctuations, so that processes and effects in the coastal zone are understood, their adverse consequences are adequately forecast, and if possible appropriate preventive measures are to be taken.
Baltic is a water basin possessing the longest series of measurements of sea levels. They have last already for over 200 years. Due to high concentration and regular location of tide gauge stations along the coast of the Baltic Sea phenomena and processes associated with raising and lowering of the sea level can be reasonably well characterized (Fig. 1).

Among the sea level fluctuations periodic and non-periodic oscillations are distinguished depending on the driving forces. However, depending on the duration time of sea level change, short-term, seasonal and long-term fluctuations can be determined.

Aim of this study is to analyze the variability of short-term, seasonal and long-term fluctuations in water levels of the Southern Baltic Sea. This analysis was based on a long-term observational series 
derived from sea level gauge stations recorded by water-gauges stations of the Polish coast.

Short-term fluctuations are the changes of the sea level recorded within several minutes to a few days. They include sea level oscillations which are intermediate between wind-generated waves and seasonal sea level changes. The most important parts of short-term sea levels changes

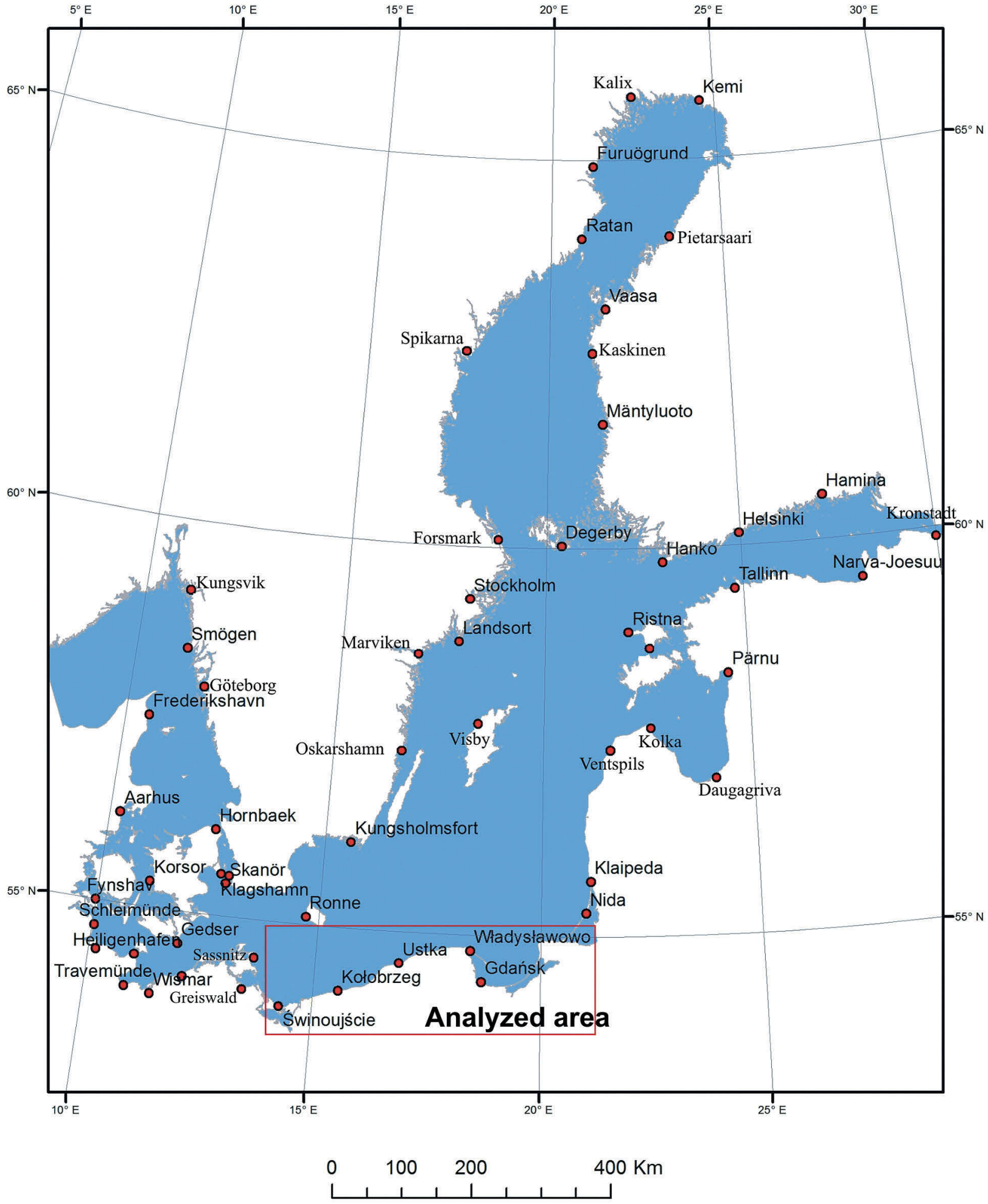

Fig. 1. Location tide gauge stations on the Baltic Sea coast 
are the phenomena known as storm surges. The coastal protection services describe a storm surge as a dynamic rise of the sea level above the alarm or warning level, induced by the action of wind and atmospheric pressure on the sea surface. The activity of the atmospheric pressure causes deformation of the sea surface, the so-called baric wave or seiche. Usually, the influence of the atmospheric pressure and baric wave occurs simultaneously. Also, it might cause flooding. Table 1 summarizes the available data on the absolute maxima and minima of sea level for the period from 1872 to 2010 for the gauge stations of the Polish coast.

Seasonal fluctuations deemed to be changes of the position of the mean sea level during a year, which are associated with filling up of the basin. In particular years, the size of these fluctuations is sometimes several times larger than the average multiyear value for a given area. It is connected with the annual variability of winds and atmospheric pressure. For the Baltic Sea, which is an internal sea, the seasonal fluctuations are caused by:

- the size of the filling up of the water basin which depends mainly on the direction and rate of exchange of water in the Baltic-North Sea system

- on long-term changes in hydrological and meteorological factors such as precipitation, evaporation, river runoff - the factors related to water balance,

- on difference in water density in various parts of the Baltic.

Certainly, these factors have a direct impact on the formation of the sea surface. However, as the primary cause of the seasonal changes in sea level during the one year is considered the characteristics of the annual and semi-annual oscillations (the annual and semi-annual solar tide).

Long-term sea level fluctuations are characterized by oscillations at a few, a several or a dozen of years intervals, and are caused mainly (except for geological reasons) by long-term changes in the course of the meteorological and hydrological conditions.

As proposed in the current climatological literature, the global climate is rapidly warming, and effects are made to pinpoint anthropogenic effects (the increased atmospheric concentration of $\mathrm{CO}_{2}$ and other glasshouse gases via fossil fuel combustion) as the underlying causes. Evidence of the changes is sought also in areas other than the global atmospheric temperature increase; a rise in the sea and ocean level being used as additional support. The report published by the Nongovernmental International Panel on Climate Change (NIPCC 2008) has summarized opinions on the causes of the sea level rise presented by the four IPCC reports of 1990, 1995, 2001, and 2007. All those reports refer to melting of mountain glaciers, small and gigantic icecaps of Greenland and the Antarctic, as well as thermal expansion. The reports contain the following, gradually decreasing, maximum estimates of the sea level rise by 2100: 367 (IPCC 1990), $124 \mathrm{~cm}$ (IPC 1995), $77 \mathrm{~cm}$ (IPCC 2001), and $59 \mathrm{~cm}$ (IPCC 2007).

Consequently, a question arises as to which scenario is the closest one to the hitherto known sea level records from the Polish coast. To address this question, the present authors made an attempt to identify trends in multi-annual and

Table 1. Extreme sea levels [cm] along the Polish coast (Wiśniewski, Wolski 2009) (tide gauge zero $=500 \mathrm{~cm} \mathrm{N.N.)}$

\begin{tabular}{|l|c|c|c|c|}
\hline \multicolumn{1}{|c|}{ Tide-gauge } & Maximum sea level [cm] & Date of occurrence & Minimum sea level [cm] & Date of occurrence \\
\hline Świnoujście & 696 & 10 Feb 1874 & 366 & 18 Oct 1967 \\
\hline Dziwnów & 615 & 10 Feb 1874 & 410 & 4 Feb 1960 \\
\hline Kołobrzeg & 722 & 13 Nov 1872 & 370 & Nov 1979 \\
\hline Darłowo & 659 & 9 Jan 1914 & 393 & 10 Feb 1897 \\
\hline Ustka & 668 & 15 Dec 1898 & 396 & 31 Dec 1890 \\
\hline Łeba & 668 & 15 Dec 1898 & 403 & 4 Nov 1979 \\
\hline Władysławowo & 644 & 23 Nov 2004 & 412 & Jan 1904 \\
\hline Hel & 622 & 14 Jan 1993 & 405 & Feb 1937 \\
\hline Gdynia & 632 & 16 Dec 1843 & 414 & 20 Jan 1887 \\
\hline Gdańsk & 664 & 5 Dec 1899 & 413 & 10 Feb 1897 \\
\hline Świbno & 702 & & & \\
\hline
\end{tabular}


century-old changes in the mean sea level; the results were used to verify the scenarios for the Polish coast.

\section{Materials and methods}

Measuring material that has been used in this study is primarily hourly, maximum, minimum and average monthly and annual average sea level values for gauge stations of the Polish coast. These data were compiled by the authors based on the publication from: Catalogues of sea level storm surges and falls... (Wiśniewski, Wolski 2009), Baltic Hydrological Sea Annals (yearbooks 1947-1970), Marine Hydrological-Meteorological Bulletins (yearbooks 1961-1990) and Environmental Conditions in the Polish Zone of the Southern Baltic (yearbooks 1986-2001) as well as on data sets purchased from the Institute of Meteorology and Water Management (IMWM) for the needs of the research project "Extreme meteorological and hydrological events in Poland" (Project No. PBZ_KBN-09/PO4/2004) and project Extreme sea levels on the coasts of the Baltic Sea (Project No. 2011/01/B/ST10/06470). For the purpose of this work, the data were standardized to a single water level gauge datum, i.e. $-500 \mathrm{~cm}$ N.N. for the Polish coast.

The analysis was performed for two characteristic storm surge events differing in the effects of the baric wave factor on the maximum sea level rise or fall. The events selected occurred on 1719 October 1967 and 13-14 January 1993. In this work the values of the static and dynamic deformation of the sea surface as the result of the passage of a baric low were calculated. For this purpose, we used the following formulae (Lisowski 1961, Wiśniewski.1996, 1997, 2005a, Wiśniewski, Wolski 2009):

$$
\Delta H_{s}=\frac{\Delta p}{\rho \cdot g},
$$

where:

$\Delta H_{s}[\mathrm{~cm}]$ - static increase in sea level at the centre of the low pressure area,

$\Delta p[\mathrm{hPa}]$ - rise or fall in atmospheric pressure in relation to its average value, i.e. 1013.2

$\rho$ - mean water density $-1.010 \mathrm{~g} \mathrm{~cm}^{-3}$,

$g$ - acceleration due to gravity $-981 \mathrm{~cm} \mathrm{~s}^{-2}$. and

$$
\Delta H_{d}=\frac{\Delta H_{s}}{1-\left(V_{L} / \sqrt{g \cdot H_{m}}\right)},
$$

where:

$\Delta H_{d}[\mathrm{~cm}]-$ dynamic deformation of sea level, $V_{L}\left[\mathrm{~m} \mathrm{~s}^{-1}\right]$ - travelling velocity of the air pressure system,

$H_{m}[\mathrm{~m}]$-- average sea depth in the outer port.

The calculations were performed for five ports (tide-gauge stations) on the Polish coast: Świnoujście, Kołobrzeg, Ustka, Władysławowo and Gdańsk. In addition, the following characteristics were determined for each storm surge:

- $\left(p_{i}\right)$ - the pressure at the centre of the depression $[\mathrm{hPa}]$,

- the initial sea level [cm] (the sea level prior to the occurrence of an extreme event),

- extreme values of the sea level during the surge and their amplitude [cm],

- rates of the maximum sea level rise and fall [ $\mathrm{cm} \mathrm{h}^{-1}$.

Sea level changes during each storm surge event were illustrated by graphs, and synoptic maps showing the passage of the low pressure systems involved were developed. In addition, the baric situation during each event was described, with reference to the course of the storm surge along the Polish coast.

For seasonal changes in sea level, spectral analysis of time series (Fourier analysis) were used for the Świnoujście station (period 1811-2010) to find oscillations that can have an impact on the annual course of the sea level. Spectral analysis is used to explore the harmonic structure of a time series. It decomposes a time series, containing cyclic components, into a number of basic sine and cosine functions with defined wavelengths (frequencies) to identify those particularly strong or important - the periodogram. The sine and cosine functions are independent of each other (orthogonal); therefore, to obtain a periodogram, squared coefficients for each frequency (period) can be added. Values of the periodogram used were calculated as (Bloomfield P. 2000):

$$
S(f)=\frac{\Delta}{n}\left(\left(\sum_{t=-n}^{n-1} x_{t} \cos (2 \pi f t \Delta)\right)^{2}+\left(\sum_{t=-n}^{n-1} x_{t} \sin (2 \pi f t \Delta)\right)^{2}\right.
$$


where:

$f$ - is the frequency,

$n-$ is the number of observations in the time series $x_{t^{\prime}}$

$\Delta-$ is $(n+1) / 2$ for $\mathrm{n}$ odd and $(n+2) / 2$ for $\mathrm{n}$ even.

Seasonal variability of sea levels is presented in tabular form for the period 1948-2006 for gauges station: Świnoujście, Kołobrzeg, Ustka, Władysławowo and Gdańsk. Characteristic levels: WWW - the highest recorded sea level during the observation period, (maximum level), SWW - the mean of the highest, SSW - mean level, SNW - the mean of the lowest, NNW - the lowest observed sea level during the observation period (minimum level) were set. The amplitude between the extremes of annual sea levels were determined for all stations.

Analyses of long-term sea levels changes included the determination of trends in change of the multiyear mean sea level for each gauge station. The gauge stations: Świnoujście (period 1811-2010), Kołobrzeg (period 1901-2010) and Gdańsk (period 1886-2010) are characterized by a very long observational series of sea level data and can well reflect long-term tendencies of such changes. In order to compare more locations at the coast and, at the same time, to maintain the comparability of the measurement data, the analysis covered the period of 1947-2010. Uniform series of data on the sea level, used in this work, were collected at the Polish coastal water gauge stations in Świnoujście, Kołobrzeg, Ustka, Łeba, Władysławowo, Hel, Gdynia, and Gdańsk. Addi- tionally, the analyses include data from the shore stations in the lagoons (Tolkmicko in the Vistula Lagoon and Trzebież in the Szczecin Lagoon) and from Szczecin, as changes in the water level at those stations may be associated with effects of the sea level variability. The methodology includes the least squares method to determine the parameters of the linear regression (trends) and 11-year moving average to present the cycles of sea level fluctuations.

\section{Results}

\section{The variability of short-term fluctuations of sea level}

Table 2 contains data describing the features of the baric lows, observed sea levels, as well as static and dynamic deformations of the sea surface, calculated using formulae (1) and (2), in the vicinity of the ports listed above. The static surge is reliable for the southern Baltic for a stationary baric low centre. The dynamic sea surface deformation ought to characterize the actual effect of the low on the sea level in the vicinity of the coast, but it does not involve the so-called shallow water factors such as friction, energy dissipation rate in outer port and the roads. The mathematical expression of such factors has to be yet developed for storm situations. The world's literature contains shallow-water factors for tides, i.e. regular, periodic sea level changes.

Table 2. Parameters of the storm surges and falls analysed

\begin{tabular}{|c|c|c|c|c|c|c|c|c|c|c|c|c|}
\hline \multirow{3}{*}{$\begin{array}{l}\text { The } \\
\text { storm } \\
\text { date }\end{array}$} & \multirow{3}{*}{ Port } & \multirow{3}{*}{$\begin{array}{l}\mathrm{H}_{\mathrm{m}} \\
{[\mathrm{m}]}\end{array}$} & \multicolumn{2}{|c|}{$\begin{array}{l}\text { Attribute of } \\
\text { depression }\end{array}$} & \multicolumn{6}{|c|}{ Observed sea level } & \multirow[b]{2}{*}{$\Delta \mathrm{H}_{\mathrm{s}}$} & \multirow[b]{2}{*}{$\Delta \mathrm{H}_{\mathrm{d}}$} \\
\hline & & & $p_{i}$ & $\mathrm{~V}_{\mathrm{L}}$ & $\begin{array}{c}\text { Initial } \\
\text { sea } \\
\text { level }\end{array}$ & Max & Min & $\begin{array}{c}\text { Ampli- } \\
\text { tude }\end{array}$ & $\begin{array}{l}\text { Maximum } \\
\text { sea level } \\
\text { rise rate }\end{array}$ & $\begin{array}{c}\text { Maximum } \\
\text { sea level } \\
\text { fall rate }\end{array}$ & & \\
\hline & & & {$[\mathrm{hPa}]$} & {$\left[\mathrm{m} \mathrm{s}^{-1}\right]$} & \multicolumn{4}{|c|}{$[\mathrm{cm}]$} & \multicolumn{2}{|c|}{$\left[\mathrm{cm} \mathrm{h}^{-1}\right]$} & \multicolumn{2}{|c|}{$[\mathrm{cm}]$} \\
\hline \multirow{5}{*}{$\begin{array}{c}17-19 \\
\text { October } \\
1967\end{array}$} & Świnoujście & 30 & \multirow{5}{*}{970} & \multirow{5}{*}{19.4} & 484 & 586 & 366 & 220 & 46 & 56 & \multirow{5}{*}{43.6} & - \\
\hline & Kołobrzeg & 40 & & & 510 & 599 & 414 & 185 & 56 & 50 & & - \\
\hline & Ustka & 40 & & & 509 & 594 & 437 & 151 & 40 & 52 & & - \\
\hline & Władysławowo & 45 & & & 519 & 583 & 475 & 108 & 20 & 30 & & - \\
\hline & Gdańsk & 50 & & & 522 & 604 & 466 & 138 & 42 & 46 & & - \\
\hline \multirow{5}{*}{$\begin{array}{c}13-14 \\
\text { January } \\
1993\end{array}$} & Świnoujście & 30 & \multirow{5}{*}{972} & \multirow{5}{*}{31.9} & 476 & 540 & 392 & 148 & 72 & 40 & \multirow{5}{*}{41.6} & -48 \\
\hline & Kołobrzeg & 40 & & & 490 & 560 & 437 & 123 & 70 & 46 & & -68 \\
\hline & Ustka & 40 & & & 498 & 590 & 452 & 130 & 40 & 90 & & -68 \\
\hline & Władysławowo & 45 & & & 500 & 596 & 484 & 112 & 58 & 40 & & -80 \\
\hline & Gdańsk & 50 & & & 497 & 624 & 470 & 154 & 48 & 78 & & -94 \\
\hline
\end{tabular}




\section{The storm of 17-19 October 1967}

A deep and active low pressure system from over the British Isles was moving at a velocity of $70 \mathrm{~km} \mathrm{~h}^{-1}$ over Denmark and southern Sweden, the Baltic Sea and on towards the north-east into the White Sea (Fig. 2). The storm wind and baric wave generated by the system induced extremely large fluctuations in the Baltic sea level. The rapid passage of the low over the Baltic resulted in a characteristic sea level fall on the Polish coast on the morning of 18 October. At Świnoujście, the absolute 1946-2006 minimum of $366 \mathrm{~cm}$ was recorded. The low's centre moved that day over the Åland Archipelago. For some hours the southern Baltic, left in the rear of the baric system, experienced severe north-westerly and northerly winds. The return to equilibrium proceeded through wind-induced seiche-like changes in the sea level. At Świnoujście and Kołobrzeg, the sea level changes during $8 \mathrm{~h}$ had an amplitude of about 2 $\mathrm{m}$ (Fig. 3). It should be pointed out that, when the baric low movement is close to the value of $\sqrt{\mathrm{gH}}$, as was the case in the event of 17-19 October 1967, the denominator of formula (2) tends to 0 . In this case, formula (2) suggests that the storm situation should be covered by the resonance zone, and the result of the calculations is not reliable. On the other hand, the maximum rises and falls of the sea level, as shown by the mareograms of 17-19 October 1967, did not indicate the differences relative to the remaining surges and falls analysed.

\section{The storm of 13-14 January 1993}

On 14 January, an active low pressure system, the so-called 'junior', passed - along with atmospheric fronts - from over the North Sea via the Danish Straits into the Baltic (Fig. 4). The atmospheric low was as deep as $972 \mathrm{hPa}$. Typical of the sea level changes during that storm was the large amplitude of fluctuations in the eastern and western parts of the coast. Figure 5 show the sea level rises and falls, moving eastwards in parallel with the low centre passage (the movement of the wave crest from 04:00 to 08:00 hrs UTC on 14 January 1993). The storm surge involved a sea level deformation by the

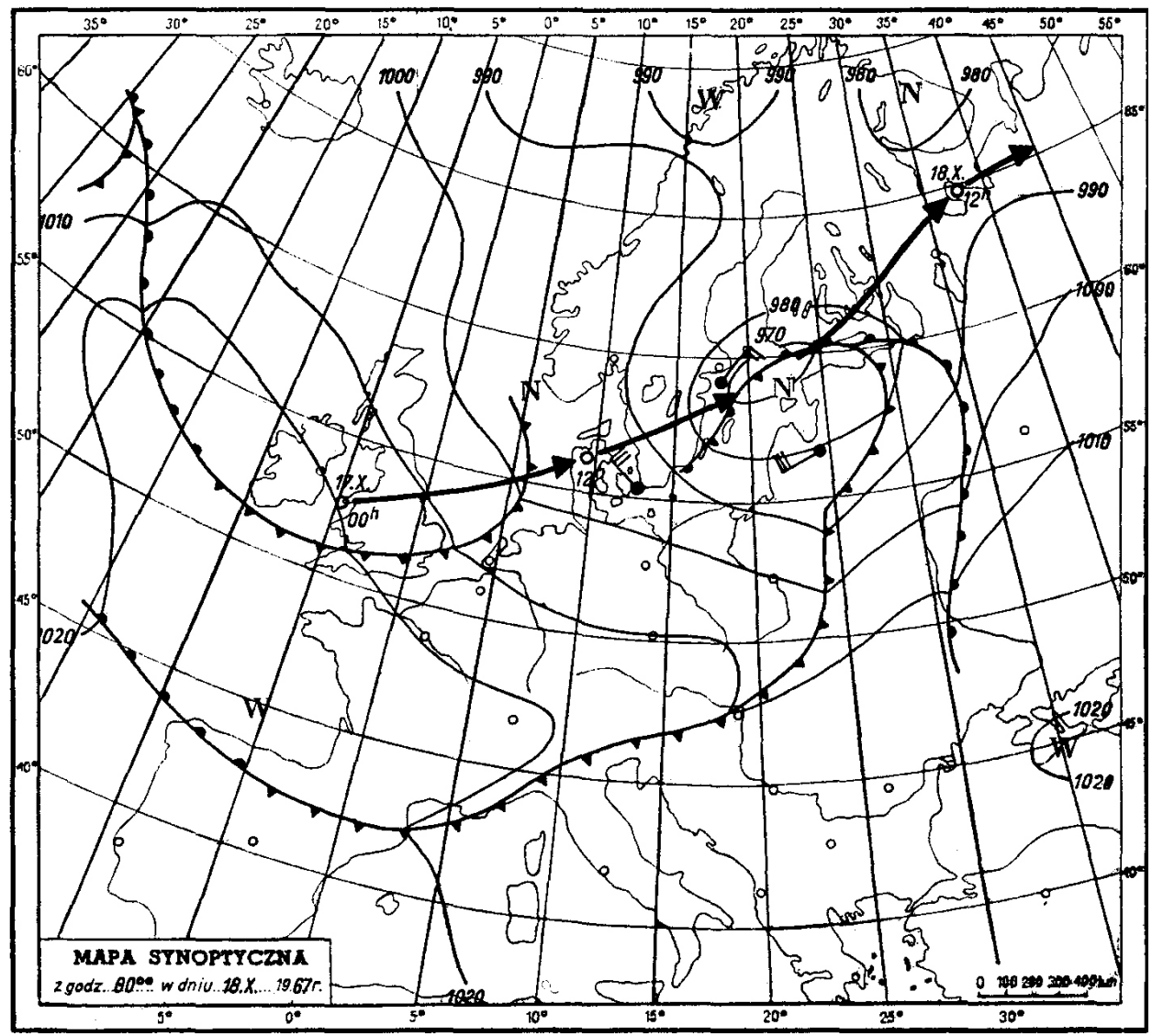

Fig. 2. Synoptic chart of the 18 October 1967 event 


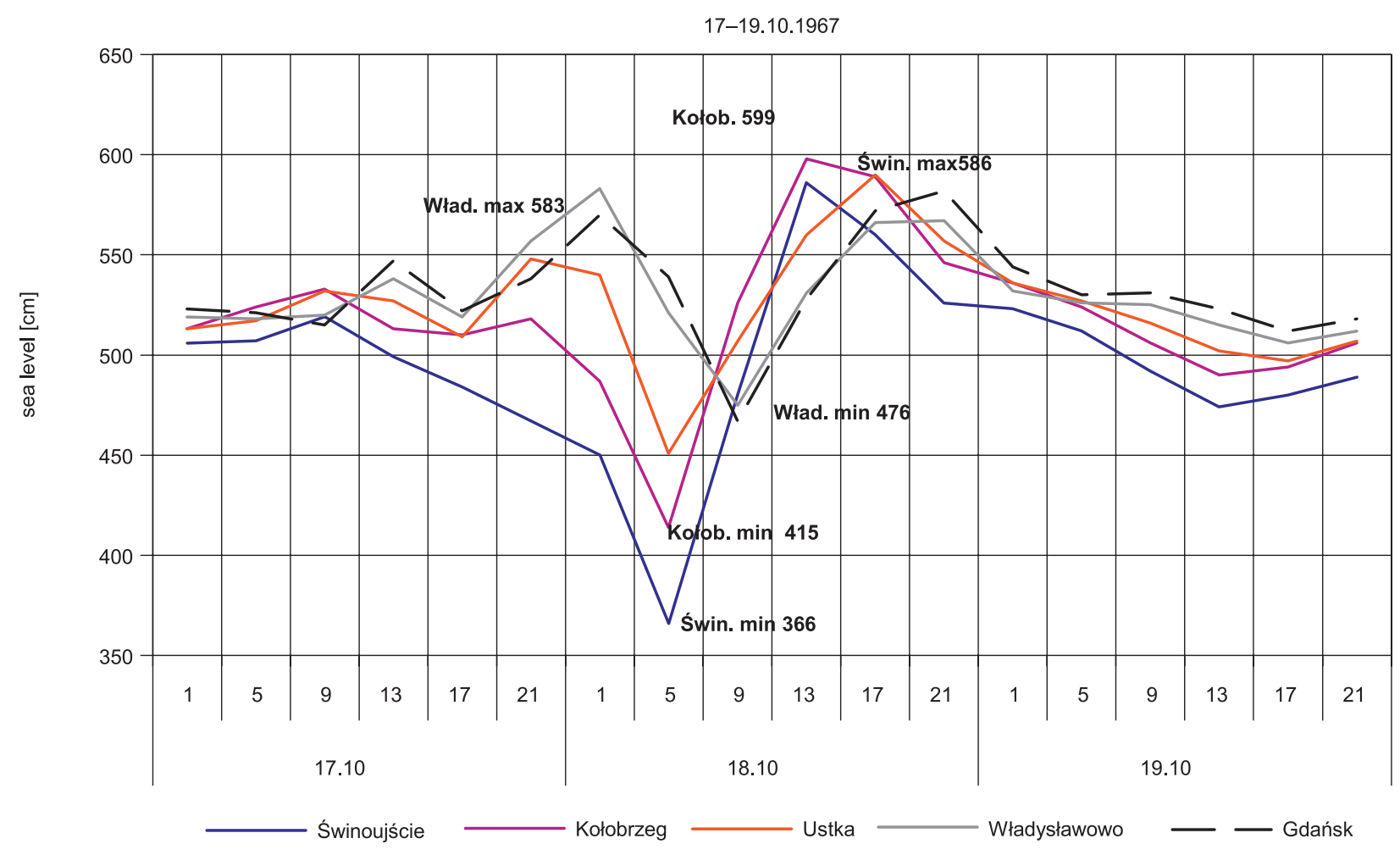

Fig. 3. Example of the storm surge and fall on 17-19 October 1967 caused by the pressure-induced wave

baric wave with its positive and negative phase. Significant here was the high velocity (about 115 $\mathrm{km} \mathrm{h}^{-1}$ ) of the low's passage, which greatly affected the wave's dynamic component involving a ratio between the passage velocity and the depth of the area $\left(\mathrm{V}_{\mathrm{L}}>>\sqrt{ } \mathrm{gH}_{\mathrm{m}}\right)$. Considering the inaccuracy with which formula (2) models the actual situation, the involvement of the wind field in the sea surface deformation in the low is visible on the mareograms of 14 January 1993 (Fig. 5). An important feature of the storm surge in question was the very rapid rise and fall of the sea level (Table 2), which is of significant practical importance for forecasting the under-keel clearance when a ship enters or leaves a port. The storm lasted for scarcely 5 hours, but in that time caused severe damage on the coast and triggered the Jan Heweliusz ferry disaster at sea.

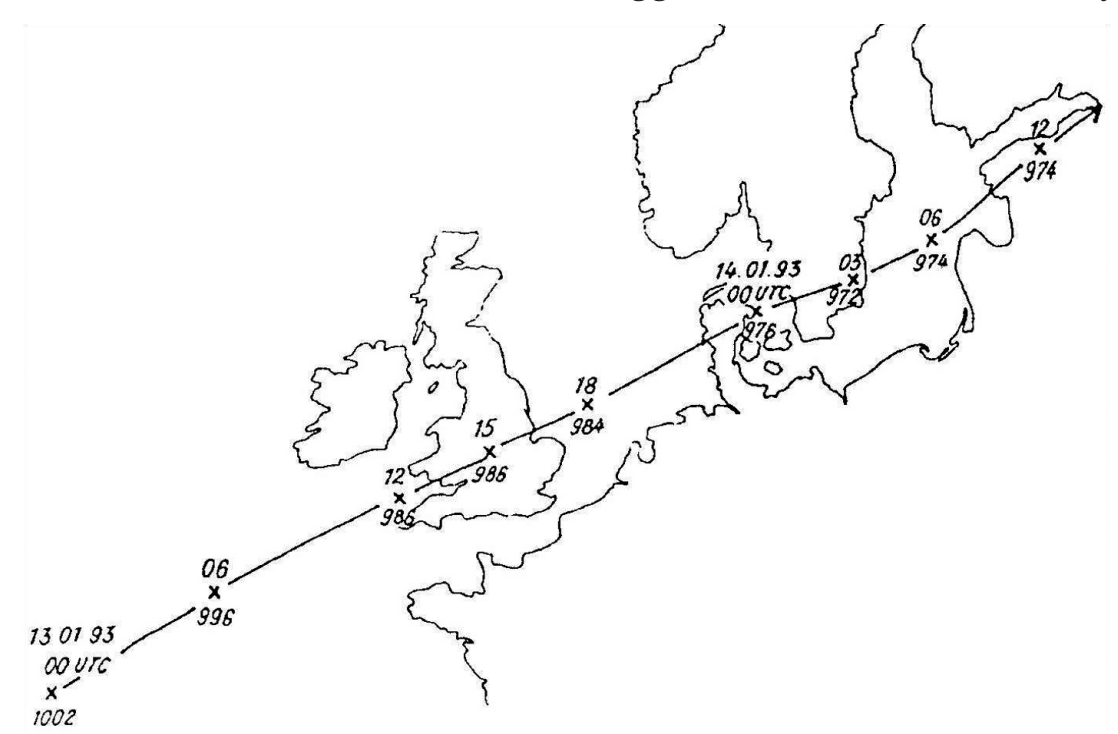

Fig. 4. The route of centre of storm low-pressure system hPa for the period 13th of January, 00 UTC to 14th of January, 12 UTC, 1993 (Wiśniewski 1997) 


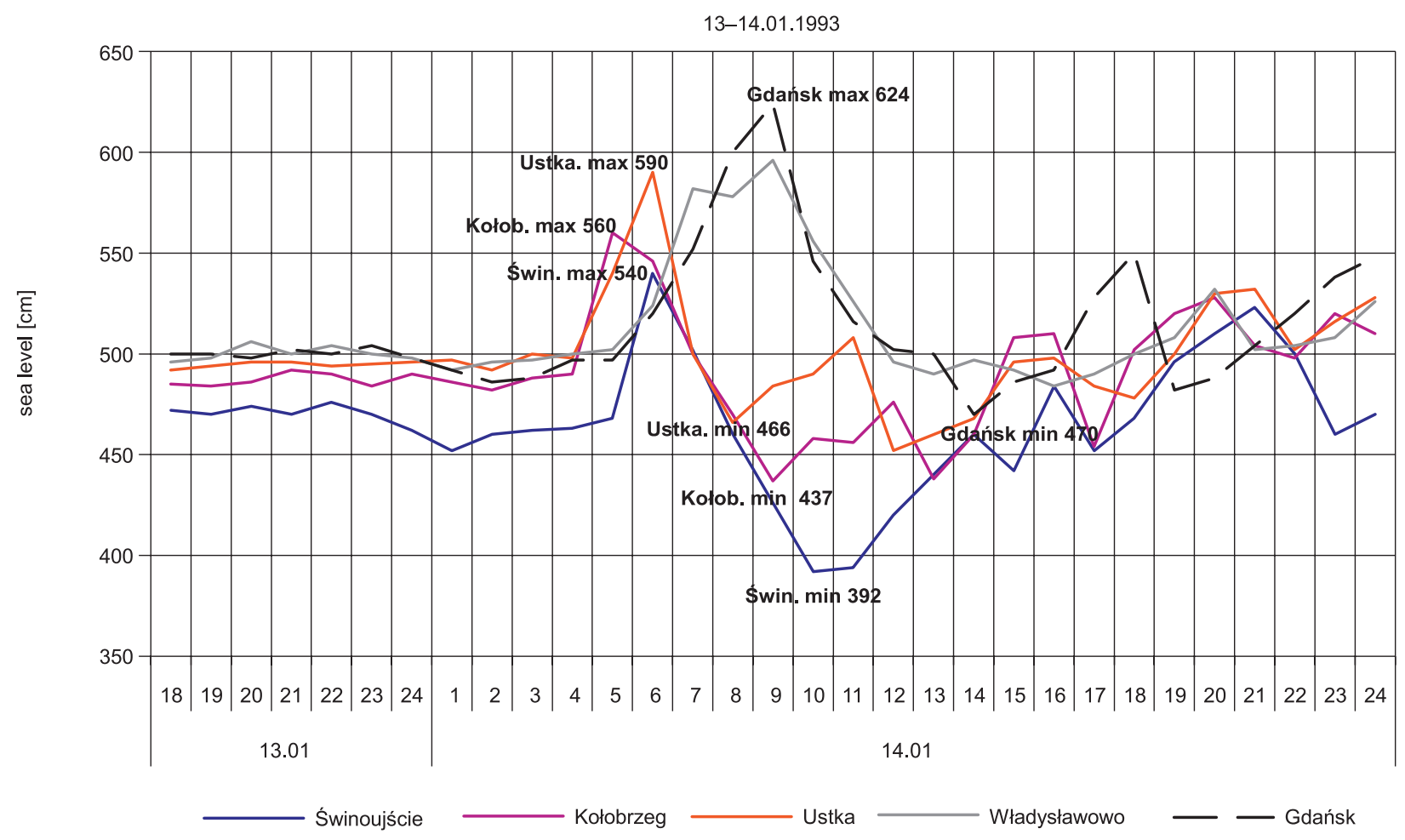

Fig. 5. Changes in sea level along the Polish Baltic coast from 18.00 hrs 13 January to 24.0014 January 1993

\section{Seasonal fluctuations of sea level}

At Świnoujście, semi-annual and annual oscillations were clearly found among the fluctuations of the average water level. All the oscilla- tions significantly exceeded the 0.95 confidence level. Other possible but less likely oscillations were 3-year, 5.6-year, 11-year, 18-year, and 90year. The oscillations are presented graphically in Figure 6.

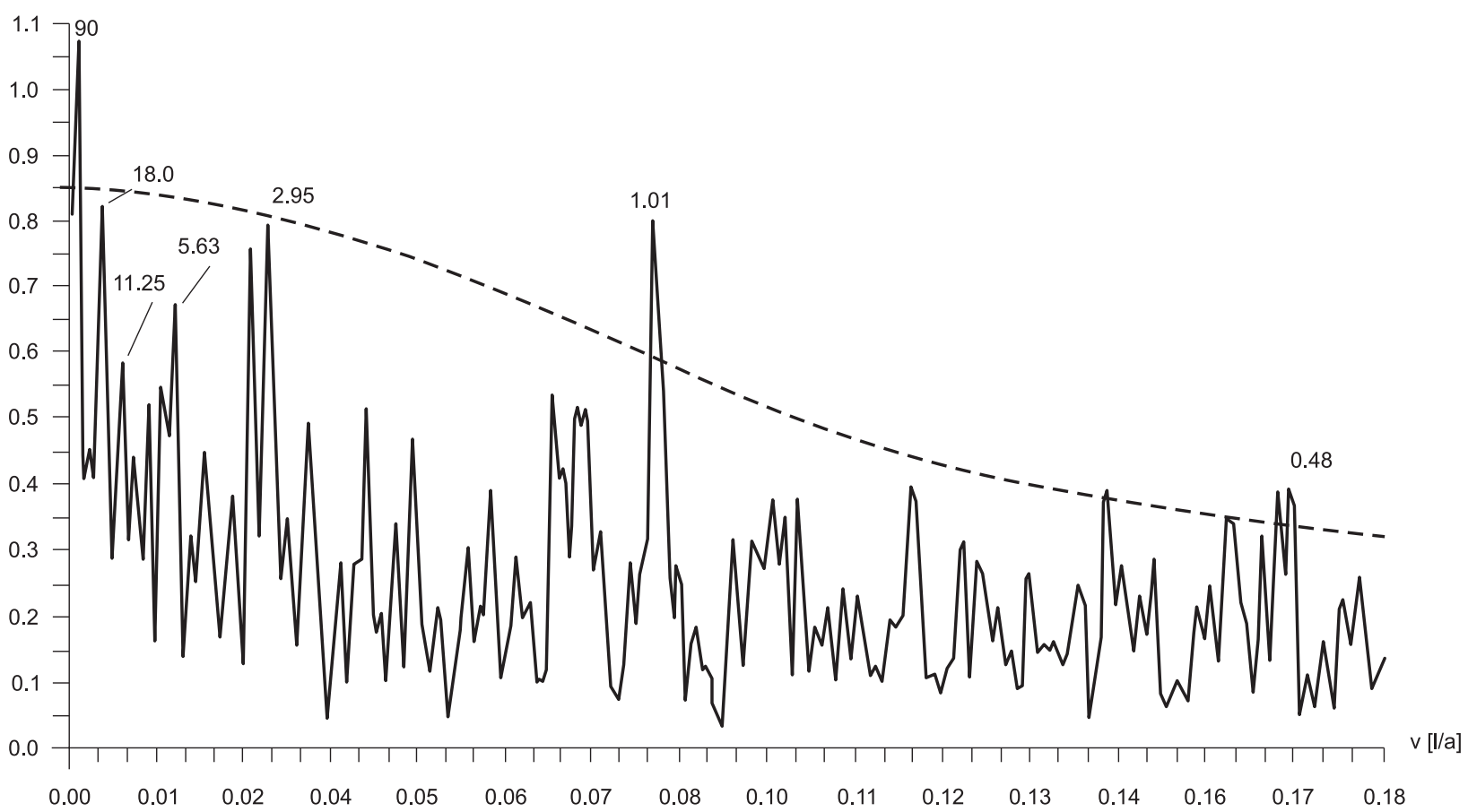

Fig. 6. Spectrum of monthly-normalised sea level values in Świnoujście. Dashed line-significance level $(\alpha=0.05)$ for deviations from red noise 
Thus, the interpretation of seasonal fluctuations should not be limited only to the annual radiation cycle. The annual and semi-annual solar tide should be mentioned among the phenomena that affect the annual distribution of mean sea level changes.

Seasonal variability of mean and extreme sea levels for the period 1947-2010 for the stations Świnoujście, Kołobrzeg, Ustka, Władysławowo and Gdańsk are presented in Table 3 and Figure 7. Characteristics of extreme sea levels shows that they occur in the autumn and winter from October to April. Extreme WWW and NNW levels were shown in the background of seasonal changes in average sea levels for the month (SWW, SSW, SNW). For all stations, the course of seasonal changes of the sea level is brought closer. It differs only with amplitudes among extreme annual values: the absolute amplitude in Świnoujście in this period is $3.03 \mathrm{~m}$, in Kołobrzeg - $2.77 \mathrm{~m}$, in Ustka and Władysławowo - $2.32 \mathrm{~m}$ and in Gdańsk - $2.30 \mathrm{~m}$.

\section{The variability of long-term fluctuations of sea level}

The secular trend in changes and fluctuations of the sea level at the Polish coast is well represented in a series of annual mean sea levels in Świnoujście over 1811-2010. It is the longest series of observation data at the Polish coast. Secular trends can be identified at other stations as

Table 3. Characteristic sea levels [cm] for Świnoujscie, Kołobrzeg, Ustka and Gdańsk from the period 1947-2010

\begin{tabular}{|c|c|c|c|c|c|c|c|c|c|c|c|c|c|}
\hline Stations & \multicolumn{12}{|c|}{ Months } & $1947-2010$ \\
\hline Świnoujście & I & II & III & IV & $\mathrm{V}$ & VI & VII & VIII & IX & $\mathrm{X}$ & XI & XII & \\
\hline WWW & 639 & 648 & 617 & 608 & 574 & 565 & 590 & 602 & 597 & 621 & 669 & 613 & 669 \\
\hline SWW & 569 & 555 & 543 & 535 & 525 & 529 & 533 & 536 & 548 & 553 & 564 & 563 & 546 \\
\hline SSW & 500 & 499 & 493 & 493 & 492 & 498 & 505 & 504 & 504 & 501 & 502 & 503 & 500 \\
\hline SNW & 437 & 445 & 448 & 460 & 467 & 473 & 480 & 473 & 463 & 449 & 441 & 440 & 456 \\
\hline NNW & 400 & 404 & 412 & 423 & 448 & 456 & 455 & 430 & 413 & 366 & 370 & 379 & 366 \\
\hline Kołobrzeg & I & II & III & IV & $\mathrm{V}$ & VI & VII & VIII & IX & $x$ & XI & XII & \\
\hline WWW & 643 & 630 & 603 & 620 & 565 & 560 & 586 & 584 & 603 & 599 & 647 & 623 & 647 \\
\hline SWW & 571 & 554 & 544 & 533 & 520 & 528 & 533 & 537 & 548 & 554 & 568 & 563 & 546 \\
\hline SSW & 504 & 500 & 492 & 492 & 491 & 497 & 506 & 505 & 506 & 504 & 505 & 506 & 501 \\
\hline SNW & 449 & 452 & 452 & 463 & 468 & 475 & 483 & 478 & 470 & 460 & 452 & 452 & 463 \\
\hline NNW & 403 & 400 & 411 & 442 & 449 & 458 & 458 & 439 & 434 & 410 & 370 & 416 & 370 \\
\hline Ustka & I & II & III & IV & $\mathrm{V}$ & VI & VII & VIII & IX & $X$ & XI & XII & \\
\hline WWW & 635 & 621 & 588 & 620 & 547 & 560 & 583 & 567 & 588 & 604 & 640 & 604 & 640 \\
\hline SWW & 564 & 546 & 537 & 529 & 518 & 527 & 534 & 535 & 544 & 552 & 564 & 558 & 542 \\
\hline SSW & 506 & 500 & 493 & 492 & 490 & 498 & 507 & 506 & 508 & 506 & 508 & 509 & 502 \\
\hline SNW & 458 & 459 & 458 & 465 & 469 & 476 & 485 & 482 & 475 & 467 & 462 & 463 & 468 \\
\hline NNW & 415 & 419 & 418 & 441 & 453 & 456 & 462 & 460 & 441 & 431 & 409 & 420 & 409 \\
\hline Władysławowo & I & II & III & IV & $\mathrm{V}$ & VI & VII & VIII & IX & $x$ & XI & XII & \\
\hline WWW & 638 & 611 & 607 & 610 & 548 & 554 & 552 & 572 & 590 & 614 & 644 & 601 & 644 \\
\hline SWW & 560 & 544 & 534 & 527 & 517 & 525 & 533 & 535 & 545 & 551 & 561 & 556 & 541 \\
\hline SSW & 509 & 501 & 492 & 492 & 491 & 498 & 508 & 507 & 508 & 507 & 509 & 510 & 503 \\
\hline SNW & 466 & 464 & 461 & 467 & 471 & 477 & 487 & 484 & 478 & 472 & 468 & 470 & 472 \\
\hline NNW & 430 & 415 & 421 & 437 & 450 & 452 & 472 & 458 & 449 & 438 & 412 & 423 & 412 \\
\hline Gdańsk & I & II & III & IV & $\mathrm{V}$ & VI & VII & VIII & IX & $X$ & XI & XII & \\
\hline WWW & 638 & 615 & 602 & 608 & 551 & 562 & 558 & 579 & 600 & 620 & 644 & 608 & 644 \\
\hline SWW & 564 & 548 & 539 & 532 & 521 & 530 & 537 & 541 & 550 & 556 & 565 & 561 & 545 \\
\hline SSW & 509 & 505 & 497 & 497 & 496 & 504 & 513 & 512 & 514 & 512 & 512 & 514 & 507 \\
\hline SNW & 467 & 467 & 465 & 472 & 476 & 483 & 492 & 489 & 483 & 475 & 470 & 473 & 476 \\
\hline NNW & 422 & 414 & 423 & 446 & 460 & 460 & 476 & 446 & 447 & 442 & 414 & 429 & 414 \\
\hline
\end{tabular}




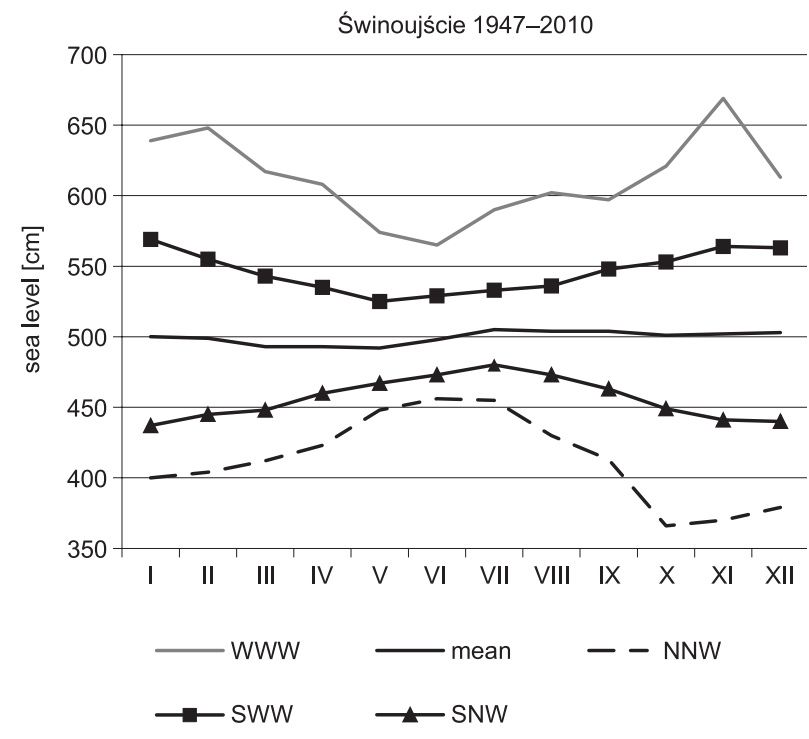

Fig. 7. Characteristic, monthly sea levels in Świnoujście (period 1947-2010)

well, but they are based on shorter observation data series.

This work show secular trends in changes of annual mean sea levels in Świnoujście (18112010), Kołobrzeg (1901-2010) and Gdańsk (18862010) (Figs 8-10). The value of the sea level rise is $0.48 \mathrm{~mm} \mathrm{y}^{-1}$ in Świnoujście, $0.60 \mathrm{~mm} \mathrm{y}^{-1}$ in Koło- brzeg and $1.61 \mathrm{~mm} \mathrm{y}^{-1}$ in Gdańsk. Another aspect of long-term changes in sea level are quasi-periodic fluctuations observed on the base of 11-year moving average sea levels. In Figure 8 appeared cycles 1820-1878 year, 1878-1927 year and 19271986 year. The cycle 1927-1986 year appeared on all three stations (Figs 8-10). This cycle is clearly cohere based on the probable common reason, i.e. climatic changes.

If you choose a different observation periods sea level on the Polish coast, we get different end results. In our study we selected the period 19472010 longest common period for all eleven major stations on the Polish coast. The trend values of the average sea level for the observation period 1947-2010 for stations on the Polish coast is presented in Table 4.

Values of the linear trend of the annual mean sea level for the recent 60 years show that the level

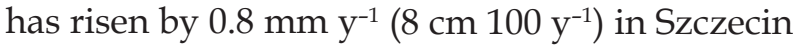

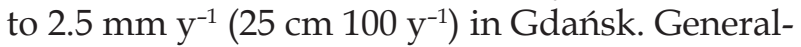
ly, the growth rate of water levels on the Polish Baltic Sea coast in the last 60 years is almost two times higher than in the same station for a period of more than one hundred years (Świnoujście, Kołobrzeg, Gdańsk).

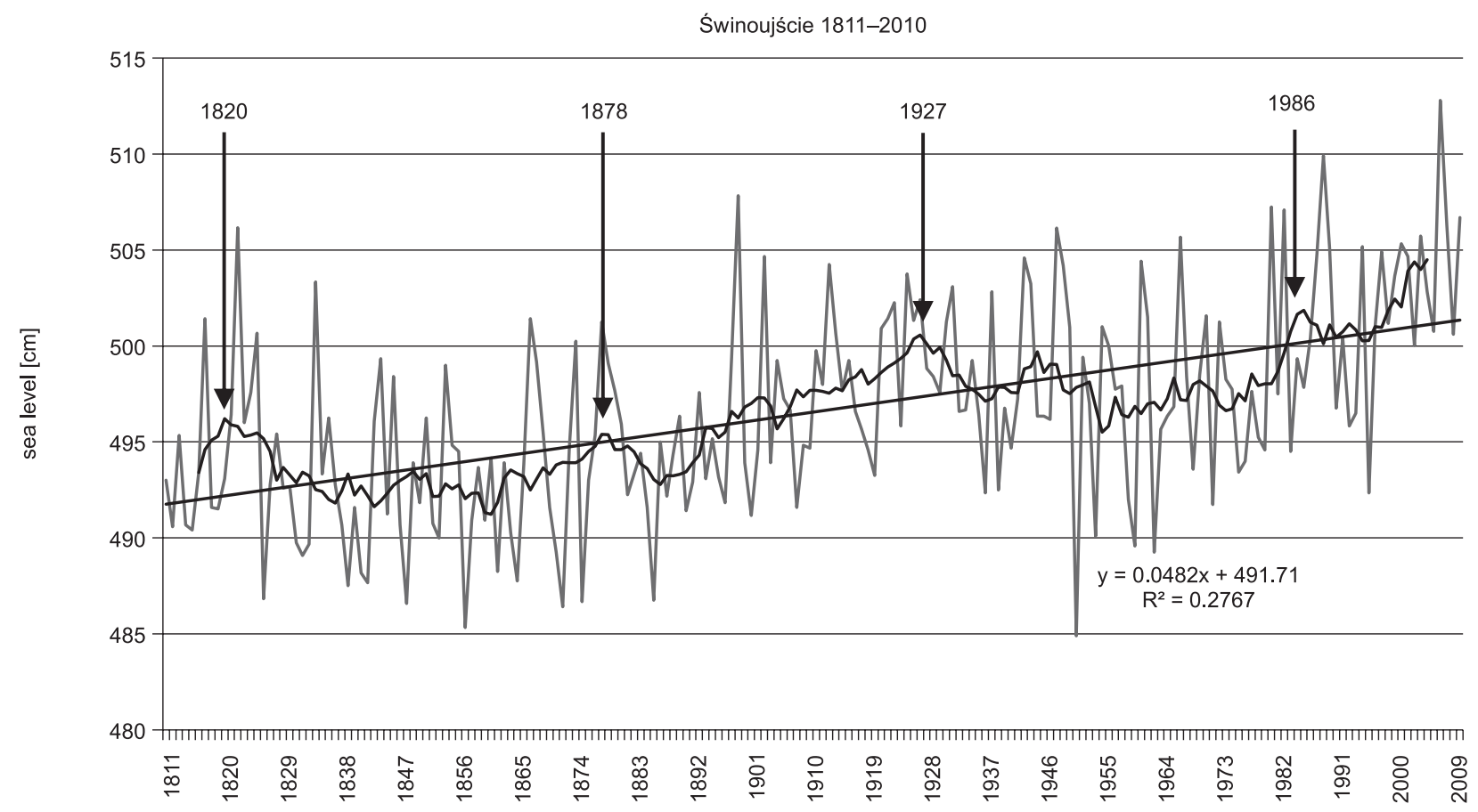

Fig. 8. Changes of the mean sea level in Świnoujście in 1811-2010 (the straight line represents the linear trend; the curve represents the 11-yr moving average) 


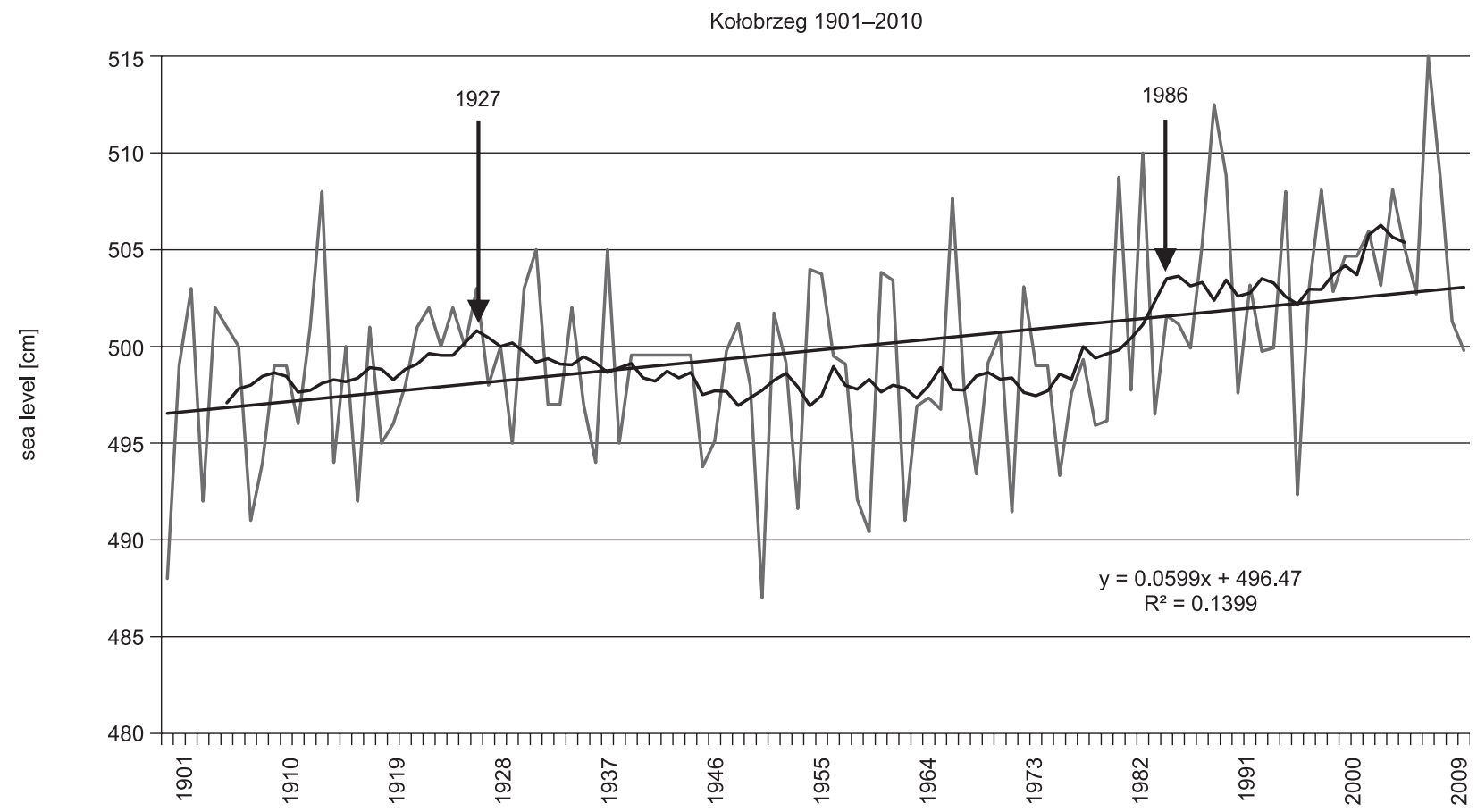

Fig. 9. Changes of the mean sea level in Kołobrzeg in 1901-2010 (the straight line represents the linear trend; the curve represents the 11-yr moving average)

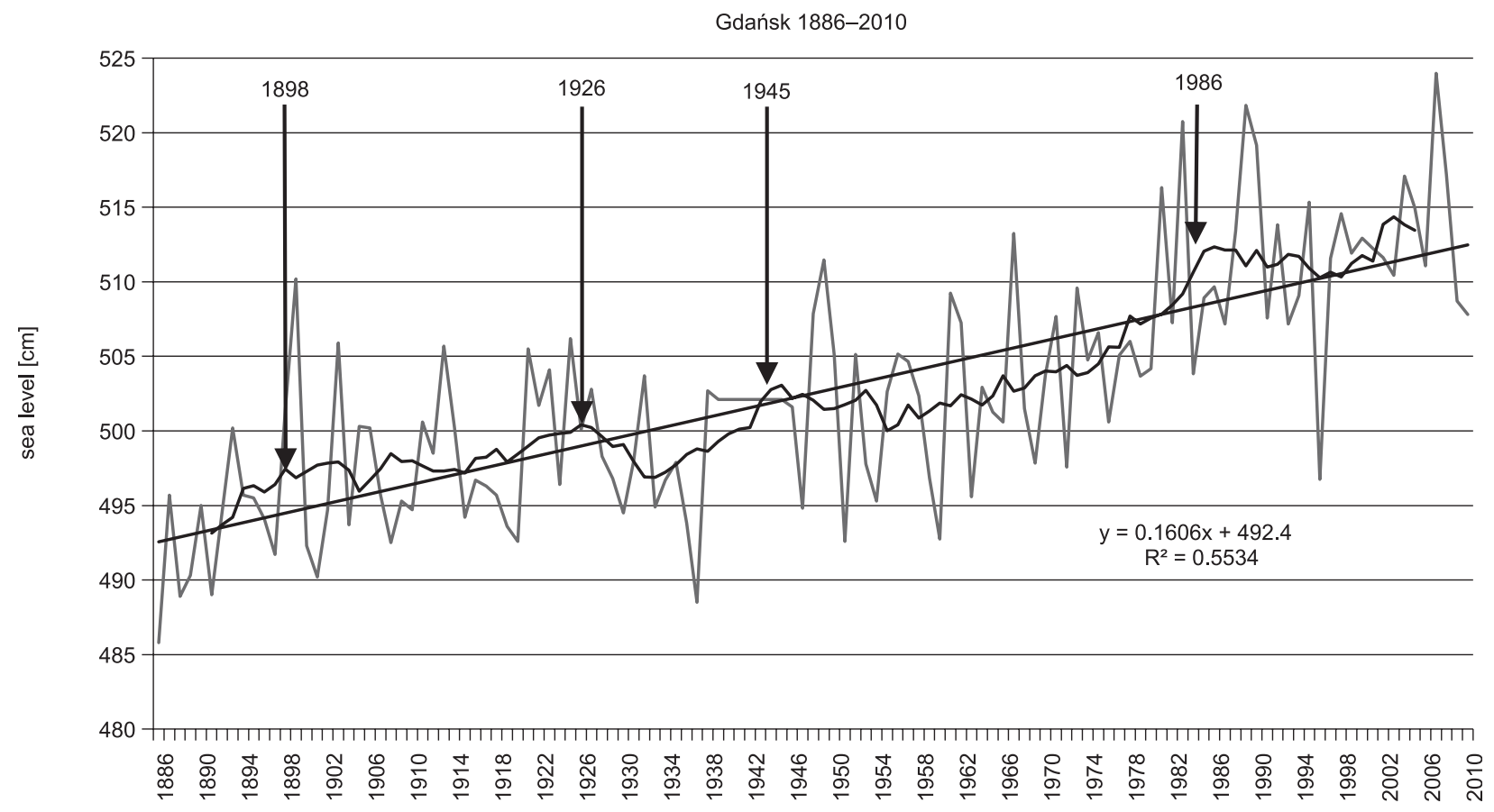

Fig. 10. Changes of the mean sea level in Gdańsk in 1886-2010 (the straight line represents the linear trend; the curve represents the 11-yr moving average) 
Table 4. Trend values of observational series sea-level in the period 1947-2010 for tide gauges stations of the Polish coast

\begin{tabular}{|l|c|c|}
\hline \multirow{2}{*}{\multicolumn{1}{|c|}{ Station }} & \multicolumn{2}{c|}{ Trend value in the period 1947-2010 } \\
\cline { 2 - 3 } & {$\left[\mathrm{mm} \mathrm{y}^{-1}\right]$} & {$\left[\mathrm{cm} \mathrm{100}^{-1}\right]$} \\
\hline Szczecin & +0.8 & +8 \\
\hline Trzebież & +1.1 & +11 \\
\hline Świnoujście & +1.2 & +12 \\
\hline Kołobrzeg & +1.5 & +14 \\
\hline Ustka & +1.6 & +16 \\
\hline Łeba & +1.0 & +10 \\
\hline Władysławowo & +1.9 & +19 \\
\hline Hel & +1.5 & +15 \\
\hline Gdynia & +2.0 & +20 \\
\hline Gdańsk & +2.5 & +25 \\
\hline Tolkmicko & +1.7 & +17 \\
\hline
\end{tabular}

\section{Discussion of results}

\section{Short-term fluctuations in sea level}

As a rule, the occurrence of extreme sea levels - storm surges on the Polish coast, is dependent on 3 components:

- the filling up of the southern Baltic (the initial sea level prior to the occurrence of an extreme event),

- the action of tangential wind stresses in the specified area (wind directions: whether shore- or seaward; wind velocities; and wind action duration),

- deformation of the sea surface by the mesoscale deep baric lows passing rapidly over the southern and central Baltic, which produce the so-called baric waves and generate seiche-like fluctuations of the sea level in the Baltic.

The volume of water filling an area prior to the extreme sea level has been mentioned in a few publications in the Polish sea coast context (storms in the southern Baltic) (Majewski (1989, 1998, Majewski i in. 1983, Stanisławczyk, Sztobryn 2000, Sztobryn et al. 2005, Wiśniewski 1996, Wiśniewski, Wolski 2009). In the two storm situations analysed in this work, the basin filling is represented by the starting (reference) sea level prior to the occurrence of the storm-caused changes (Table 2). In this situations, the level was similar to the mean sea level (500 cm N.N.), except for the level of $476 \mathrm{~cm}$ at Świnoujście on 13 January 1993.

The role of tangential wind stresses in the emergence of drift currents and their resultant contribution to the rise or fall of sea level in the ports of an area is understandable; the magnitude of a rise or fall depends not only on the wind speed, but also on the wind duration, direction, wind fetch over the sea surface, and compensatory flows in the inshore zone. The wind effects are directly related to the pressure distribution over an area (Fig. 11).

The problem of sea level deformation by concentric, mesoscale, fast-moving deep baric lows was tackled by Lisowski (1960, 1961, 1963), Wiśniewski (1996, 1997, 2003, 2005), Wiśniewski, Holec (1983), Wiśniewski, Kowalewska-Kalkowska (2007), Wiśniewski, Wolski (2009). It seems, however, that this factor has been generally underestimated, even downright ignored, in the literature, a situation that has been detrimental to attempts at explaining mechanisms of such extreme phenomena as coastal floods or low sea levels that adversely affect navigation safety, hydrotechnical construction stability, etc.

To be sure, a lowered atmospheric pressure system (a tropical cyclone or a concentric baric low) overlies a water cushion, the so-called baric wave, moving together with the pressure system at the sea surface. The wave's height depends on the pressure decrease in the centre of the system. A pressure drop of $\Delta \mathrm{p}=1 \mathrm{hPa}$ results in a static sea level rise of $\Delta H s=1 \mathrm{~cm}$ at the stationary low (Fig. 12 a, Formula 1). When the low moves over the sea surface, the latter becomes dynamically deformed $(\Delta H d)$. The sea level deformation associated with the baric wave shows positive wave elevations in the centre and negative elevations on the flanks of the deformation (Fig. $12 \mathrm{~b}$, Formula 2). During the passage of a deep low, the sea level rise may be 2-4 times higher than the rise produced by static conditions. The fluid level deformation moves according to the laws of forced long wave propagation. When the wave propagation velocity is close to that of a baric system passage, the wave amplitude will reach large values under the dynamic parameters of the system. 


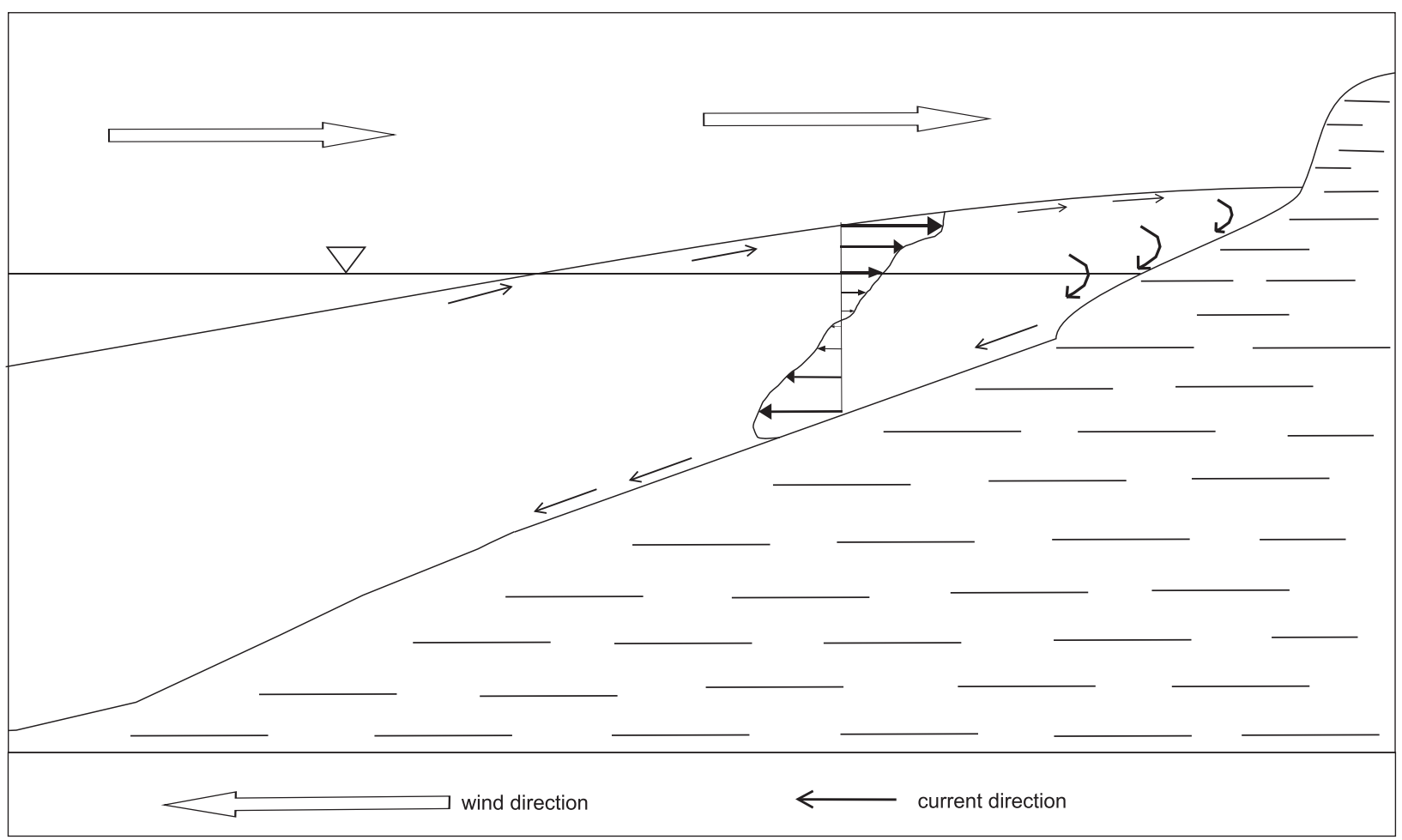

Fig. 11. Schema the inclination of the sea and the circulation of currents by the action of the wind field

As a result of the progressive movement of a baric low, the ratio of low progression $\left(\mathrm{V}_{\mathrm{L}}\right)$ to the free wave characteristics becomes important:

$$
c=\sqrt{g H_{m}}
$$

where:

$H_{m}$ - average sea depth,

$g$ - acceleration due to gravity $-981 \mathrm{~cm} \mathrm{~s}^{-2}$.

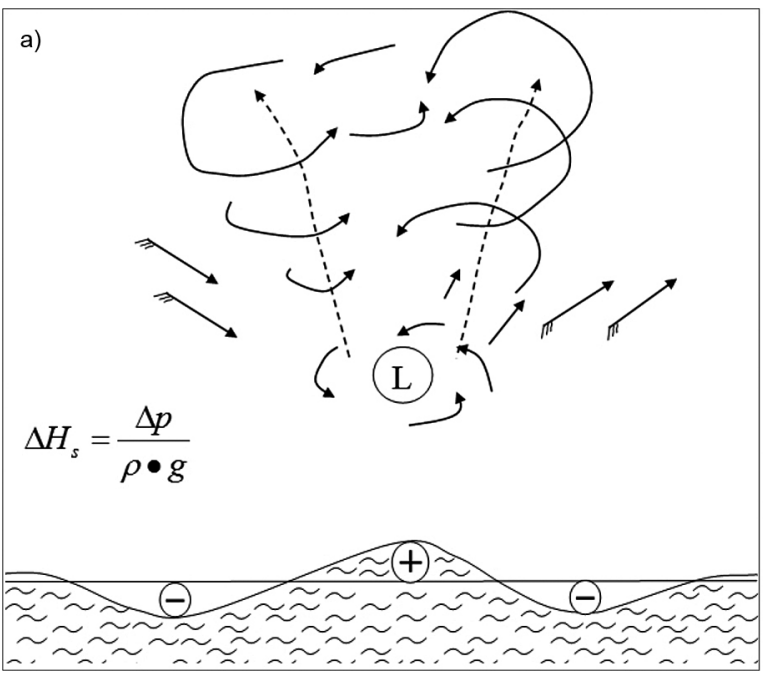

Thus, storm-generated surges and falls of sea level are a net effect of wind action and a baric wave resulting from the baric field characteristics. Wind and a baric wave can produce the same effect, i.e. both factors cause the sea level on the coast to rise or fall; they can also produce opposite effects, when one factor raises the sea level and the other lowers it. The effects of a baric wave may be several times greater than

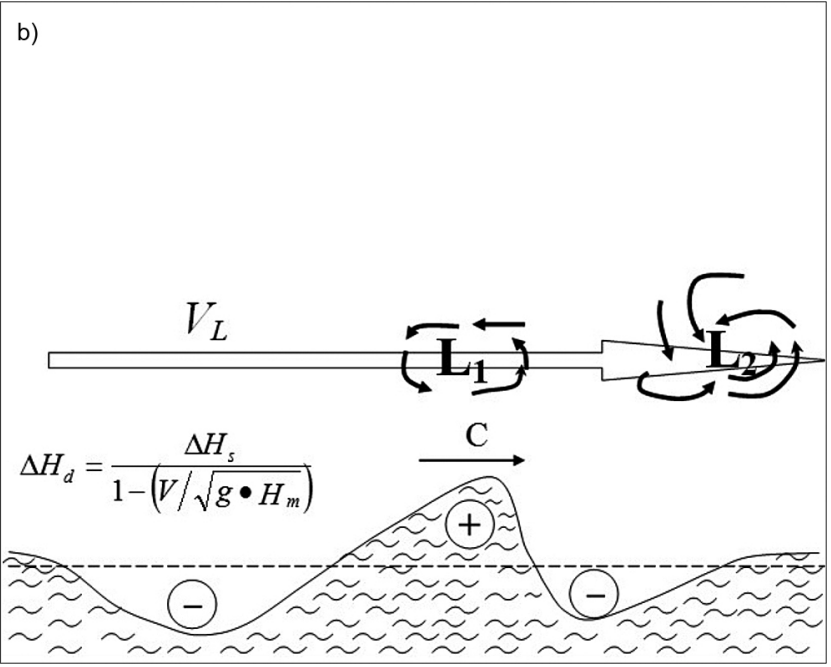

Fig. 12. Diagram of sea surface deformation caused by a low pressure system a) static sea surface deformation, b) dynamic sea surface deformation (Wiśniewski, Wolski 2009) 
those of the wind action. When the storm (baric wave, wind) abates, the sea level - knocked out of balance - will undergo free damped oscillations until equilibrium is restored (seiche-like variations).

Owing to the complexity of the phenomenon, any sea level forecast during a storm surge will be problematic. An additional difficulty is that sea level changes are greatly affected by local conditions on the coast and the seafloor relief in the shore zone and in a port. Therefore, it is necessary that the sea surface deformation factor by the rapidly moving baric low be included in future models developed to forecast storm surges and falls.

The contribution of sea surface deformation by rapidly moving, deep, mesoscale baric lows to the overall picture of sea level rises and falls is confirmed by the examples of storm events selected for this paper, i.e. 17-19 October 1967 and 13-14 January 1993 (Figs 2-5).

\section{Seasonal fluctuations in sea level}

In Figure 7 and the Table 3, presented the characteristic course of sea level during the one year for the station for the Polish coast. Maximum mean sea level in the months of July-September in Świnoujście and other stations of the Polish coast results from the domination of western circulation during the summer in the Baltic Sea (inflow of water from the North Sea). However, the dominance of eastern air flow causes the minimum water level in the Spring (March-May) (water outflow from the Baltic Sea). Seasonal changes of sea level on the Polish coast presented in this study is consistent with the effect of annual and semi-annual oscillation analyzed by Wiśniewski (1978, 2005 b). The annual oscillation (associated with the annual solar tide and change of the solar radiation) forms atmospheric circulation and therefore, it is associated with the annual cycle of sea level fluctuations. Semi-annual oscillation having a relationship with the semi-annual solar tide (the semi-annual wave) is responsible for the formation of secondary extremes. The total value of the annual and semi-annual oscillations almost completely corresponds to the annual average of the observed sea levels (Fig. 13) (Wiśniewski
1978, 2005 b). According to Wiśniewski (1978: 21) Annual oscillation has its minimum in MarchApril and a maximum in September-October. Extremes semi-annual oscillations contribute to the deepening of the minimum water level in April-May and enhance maximum water level in July-August. They also cause the formation of a secondary maximum and minimum of sea levels.

Seasonal fluctuations associated with the water balance are only background against which occur short-term fluctuations. Therefore, seasonal fluctuations should be assessed as a longterm fluctuations in the change of average water level. The value of seasonal rise or fall of the mean level is considered as a correction to determine the average water level within the given water basin during a year.

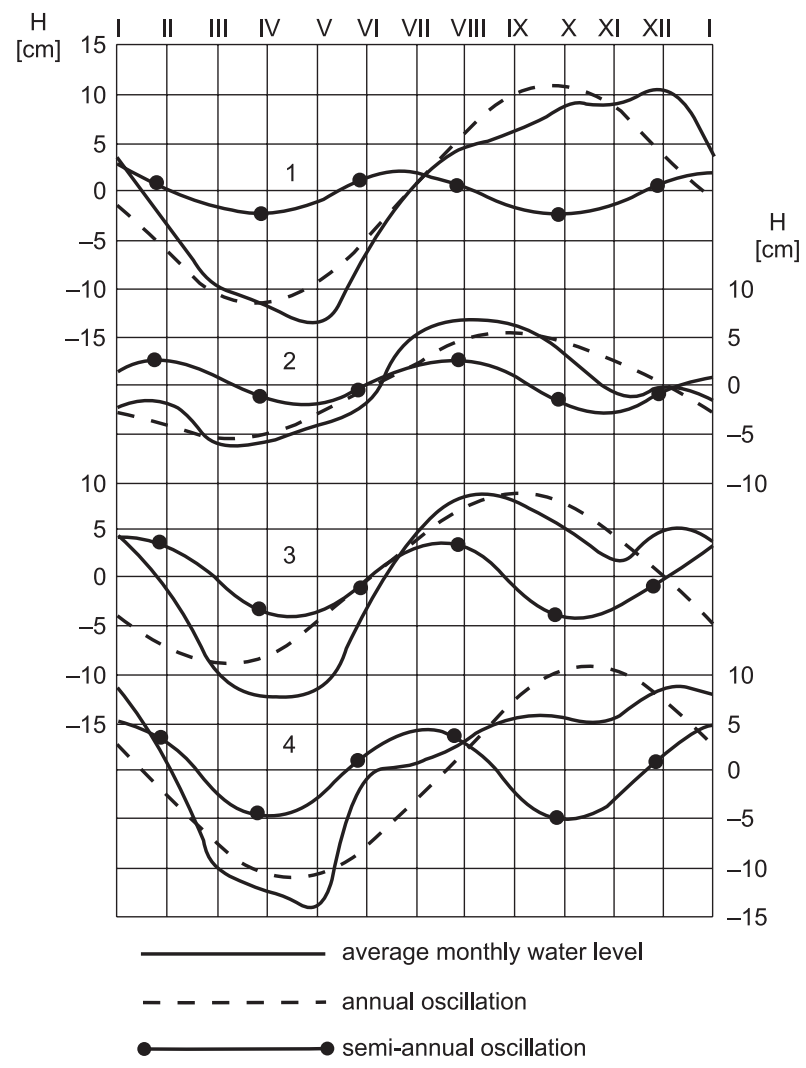

Fig. 13. Annual and semi-annual oscillation in comparison with an average, the observed annual sea level (1891-1960) in [cm] at stations: 1. Ejsberg - North Sea, 2. Gedser - Danish straits, 3. Landsort - the central part of the Baltic Sea, 4 Oulu - Gulf of Bothnia (Wiśniewski 1978). Seasonal fluctuations associated with the water balance are only background against which occur short-term fluctuations. Therefore it should be assessed as a long-term seasonal variations in the change of average water level 
Table 5. The results of some evaluations of trends of average sea level on the Polish coast

\begin{tabular}{|c|c|c|c|c|}
\hline \multirow{2}{*}{ Authors } & \multirow{2}{*}{$\begin{array}{c}\text { The observation } \\
\text { period }\end{array}$} & \multicolumn{3}{|c|}{ Trend $\left(\mathrm{mm} \mathrm{y}^{-1}\right)$} \\
\hline & & Swinoujście & Kołobrzeg & Gdańsk \\
\hline \multirow[t]{2}{*}{ Dziadziuszko Z., Jednorał T. 1988} & $\begin{array}{l}1811-1985 a \\
1868-1985 b \\
1886-1985 c\end{array}$ & 0.7 (a) & $1.1(b)$ & $1.2(\mathrm{c})$ \\
\hline & $1951-1985$ & 1.4 & 0.8 & 2.9 \\
\hline Rotnicki K., Borzyszkowska W. 1999 & 1951-1990 & 2.19 & 2.19 & 4.02 \\
\hline Jakusik et al. 2010 & $1951-2008$ & 1.8 & 1.8 & 2.9 \\
\hline \multirow[t]{2}{*}{ Wiśniewski B., Wolski T. 2011} & $\begin{array}{l}1811-2006 \mathrm{a} \\
1901-2006 \mathrm{~b} \\
1886-2006 \mathrm{c}\end{array}$ & 0.45 (a) & $0.53(b)$ & 1.57 (c) \\
\hline & $1947-2006$ & 1.0 & 1.4 & 2.5 \\
\hline
\end{tabular}

\section{Long-term and ages fluctuations in sea level}

Trends of long-term changes in mean sea level determined in this study are much lower than the ones accepted in the IPCC scenarios. Calculated trends for the Polish coast are: Świnoujście $0.48 \mathrm{~mm} \mathrm{y}^{-1}$ (in the period 1811 to 2010), Kołobrzeg $0.60 \mathrm{~mm} \mathrm{y}^{-1}$ (in the period 1901-2010) and Gdańsk $1.61 \mathrm{~mm} \mathrm{y}^{-1}$ (in the period 1886-2010) (Figs 8-10). However, for the last 60 years, the growth rate of water levels on the Polish Baltic coast is much higher. Values of the linear trend in the annual mean sea level in period 1947-2010 show that the level has risen by $0.8 \mathrm{~mm} \mathrm{y}^{-1}(8 \mathrm{~cm}$

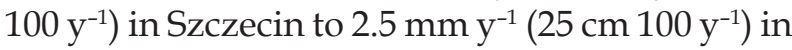
Gdańsk (Table 4). However, the obtained trend magnitudes proved to be lower than those fore-

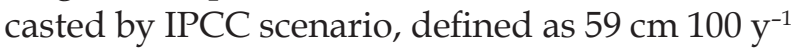
(IPCC 2008).

Generally, the results support the finding known from the literature about an accelerated mean sea level rise along the Baltic coast in the second half of the 20th century. According Hammarklint (2009) the average water level along the Swedish coast has increased from 1898 to today, about $20 \mathrm{~cm}$ that is at an average rate of $1.5 \mathrm{~mm}$ per year. The author also notes that for the last 30 years (period 1980-2009) the rate of sea level rise in the Swedish coast increased markedly elevating $3 \mathrm{~mm}$ per year. This effect is explained by climate change (global warming). A similar tendencies of rapid growth of the mean sea level in the last few years were noticed by other authors in works concerning the southern Baltic (Dziadziuszko, Jednorał 1988, Rotnicki, Borzyszkowska 1999, Jakusik et al. 2010, Wiśniewski, Wolski 2011). The values of the average sea level rise for the Polish coast in the last few years oscillate around $2 \mathrm{~mm} \mathrm{y}^{-1}$ (Table 5).

\section{Conclusions}

1. The interactions between wind and baric waves during storm surges allow one to observe that:

- the relative contributions of wind and baric wave to the resultant changes in sea level depend on mesoscale baric lows, their passage velocity and intensity. Deep (<980 hPa), rapidly moving baric lows cause sea surface deformation mainly as a result of baric wave action. When a baric low system moves at high speed, the wind action in a given direction is limited in duration. The wind energy produces waves and mixes the water, but cannot induce significant drifting surges. On the other hand, when baric systems are shallow (> 980 $\mathrm{hPa}$ ) and slow-moving, the resultant change in the sea level is brought about predominantly by the wind field;

- the type of sea level change (amplitude and timing) is greatly affected by the baric low's trajectory and its distance from the shore. A large positive wave effect occurs when the trajectory is parallel to the coast - in such a case, local conditions play an important part;

- exceptionally severe storm surges occur when the baric wave crest (positive phase) approaches the coast from the same direction as the wind;

- forecasts of storm surges should also take into account (apart from factors: wind field and rapidly moving baric low) the initial sea level prior to the occurrence of an storm event. 
2. In the seasonal fluctuations of water levels, the maximum mean sea level in the months of July - September in Świnoujście and other stations of the Polish coast results from the domination of western circulation during the summer in the Baltic Sea. The domination of eastern air flow causes the minimum water level in the spring (March-May). The characteristics of the annual and semi-annual oscillations (solar tide) is suggested to be a primary cause of seasonal changes in sea level during the year and the occurrence of secondary extremes.

3. In the period 1947-2010 the amplitude of sea level fluctuations on the Polish coast increases from east to west. Absolute amplitude in Świnoujście in this period amounted to $3.03 \mathrm{~m}$, $2.77 \mathrm{~m}$ in Kołobrzeg, Ustka and Władysławowo $2.32 \mathrm{~m}$ and $2.30 \mathrm{~m}$ in Gdańsk (Table 3).

4. The observation series of the annual mean sea levels in Świnoujście, the longest one at the Polish coast, shows that the secular trend for 1811-2010 amounts to $0.48 \mathrm{~mm} \mathrm{y}^{-1}$, i.e. the

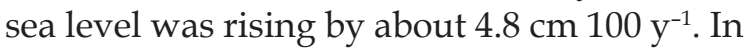
Kołobrzeg, the secular linear trend of the mean annual sea level was $0.60 \mathrm{~mm} \mathrm{y}^{-1}$ in 1901-2010, and in Gdańsk during 1886-2010 - it was 1.61 $\mathrm{mm} \mathrm{y}^{-1}$ (Figs 8-10). However, for the last 60 years the growth rate of water levels on the Polish Baltic coast is almost two times higher. In the recent 60 years of continuous observations (1947-2010), the differences between the rates determined for different parts of the coast ranged from about $1.0 \mathrm{~mm} \mathrm{y}^{-1}$ (the western part) to $2.5 \mathrm{~mm} \mathrm{y}^{-1}$ (the eastern part). According to the authors it is possible that within 100 years on the Polish coast, sea level will rise between 10 to $25 \mathrm{~cm}$. This is much lower than forecast projected by the IPCC. These results are complementary and confirm the works by other authors who partially explain the positive rate of sea levels by climate changes, or NAO index (Ekman M. 2009, Jakusik et al. 2010, Johansson M. et al. 2004).

In conclusion, it is emphasized that rising sea levels in the short-term, seasonal and long-term scale creates a lot of problems. These are: the disappearance of beaches and dunes, flooding hazard at coastal areas, the threat to economic development of coastal towns, the loss of valuable natural elements of the coastal zone environ- ment. Other problems are: threats to security and quality of people's lives as well as the necessity to incur expenses for the removal of losses associated with the erosion of shores. Following effects of the sea level rise can be expected on the Polish coast: the retreat of the coastline in the forthcoming century, irreversible loss of shore due to abrasion (ca. 10-20 km²), flood hazard which refers to considerable coastal regions and the need to bear the costs of coastal protection that may exceed the financial capacity of the state.

\section{Acknowledgments}

This work is part of the research project $E x$ treme sea levels on the coasts of the Baltic Sea No. 2011/01/B/ST10/06470 funded by the National Science Centre. Acknowledgments to the Institute of Meteorology and Water Management for providing sea levels data from the Polish tide gauge stations.

\section{References}

Bloomfield P., 2000. Fourier Analysis of Time Series: An Introduction, 2nd Edition, Wiley and Sons.

Dziadziuszko Z., 1993. Poziom morza. In: Niwelacja precyzyjna. Niwelacja geometryczna, trygonometryczna, satelitarna i hydroniwelacja, Wyd. PPWK, Warszawa-Wrocław: 351-391.

Dziadziuszko Z., Jednorał T., 1988, Wahania poziomów morza na polskim wybrzeżu Bałtyku (Sum.: Fluctuations of the sea level at the Polish Baltic coast). Studia i Materiaty Oceanologiczne 52: 215-238.

Ekman M., 2009. The Changing Level of the Baltic Sea Turing 300 Years: A Clue to Understanding the Earth. Summer Institute for Historical Geophysics, Aland Islands

Hammarklint T., 2009. The Swedish Sea Level Network. GLOSS Experts 11th Meeting 2009: 1-5.

Jakusik J., Wójcik R., Biernacik D., Pilarski M., Miętus M., Wójcik R., 2010. Zmiany poziomu morza wzdłuż polskiego wybrzeża Morza Bałtyckiego (Sum.: Changes in sea level along the Polish coast of the Baltic Sea). Studia $i$ Prace $z$ Geografii i Geologia 16: 219-234.

Johansson M., Kahma K., Boman H., Launiainen J., 2004. Scenarios for sea level on the Finnish coast. Boreal Environment Research 9.

Lisowski K., 1960. Badania zjawisk hydrometeorologicznych na Bałtyku (Sum.: Research of hydrometeorological phenomena in the Baltic). Pomorze Zachodnie 1-2: 95-108.

Lisowski K., 1963. Zjawiska sztormowe w lutym 1962 i ich skutki (Sum.: Storm phenomena in February 1962 and their consequences). Zeszyty Naukowe Politechniki Szczecińskiej 39, Budownictwo IV, Oceanologia, Szczecin: 7-30.

Lisowski K., 1961. Nieokresowe wahania poziomu Bałtyku pod wpływem czynników anemobarycznych (Sum.: Aperiodic fluctuations of the level of Baltic under the 
influence of anemobaric factors). Archiwum Hydrotechniki 8(1): 17-42.

Majewski A., 1989. Niezwykłe krótkotrwałe wezbrania morza u południowych i wschodnich brzegów Bałtyku (Sum.: Unusually short-lived sea water level oscillations on the southern and eastern coasts of the Baltic Sea). Przeglad Geofizyczny 34(2): 191-199.

Majewski A., 1998. Największe wezbrania wód u południowych brzegów Morza Bałtyckiego (Sum.: The highest storm surges along the southern coast of the Baltic Sea). Wiadomości IMGW 21(2): 81-98.

Majewski A., Dziadziuszko Z., Wiśniewska A., 1983. Monografia powodzi sztormowych 1951-1975. Wydawnictwa Komunikacji i Łączności, Warszawa: pp. 216.

NIPCC [Nongovernmental International Panel on Climate Change], 2008. Nature, Not Human Activity, Rules the Climate. Summary for Policymakers of the Report of the Nongovernmental International Panel on Climate Change. Singer S.F. (ed.), The Heartland Institute, Chicago, 40 pp.

Rotnicki K., Borzyszkowska W., 1999. Przyspieszony wzrost poziomu morza i jego składowe na polskim wybrzeżu Bałtyku w latach 1951-1990 (Sum.: Accelerated sea-level rise and its components at the Polish Baltic coast in the years 1951-1990). Ewolucja systemów nadmorskich Południowego Bałtyku, Borówka R.K. (ed.), Bogucki Wydawnictwo Naukowe, Poznań-Szczecin: 141-160.

Stanisławczyk I., Sztobryn M., 2000. Zmiany napełnienia Bałtyku jako wskaźnik oceanicznych wlewów powierzchniowych (Sum.: Changes in water volume in the Baltic Sea as an indicator of surface inflows). XII Międzynarodowa Konferencja Naukowo-Techniczna - Rola Nawigacji w Zabezpieczeniu Działalności Ludzkiej na Morzu, Wydawnictwa Akademii Marynarki Wojennej, Gdynia: 250-256.

Sztobryn M., Stigge H.J., Wielbińska D., Weidig B., Stanisławczyk I., Kańska A., Krzysztofik K., Kowalska B., Letkiewicz B., Mykita M., 2005. Storm surges in the southern Baltic (western and central parts). Report No. 39, Berichte des Bundesamtes für Seeschifffahrt und Hydrographie, Hamburg and Rostock: 74.

Wiśniewski B. 2002. Oddziaływanie niżów barycznych na stany wód w Estuarium Odry. In: Geotechnika w warunk- ach oddziaływania morza, Wydawnictwo Politechniki Szczecińskiej: 159-171.

Wiśniewski B., 1978. Sezonowe i wieloletnie wahania poziomu wód Morza Battyckiego, Wydawnictwo Wyższej Szkoły Morskiej, Szczecin.

Wiśniewski B., 1996. Wezbrania sztormowe na polskim wybrzeżu Bałtyku (Sum.: Storm surges on the Polish coast of the Baltic Sea). Wspótczesne Problemy Inżynierii Środowiska Wodnego, 50-lecie Wydziału Budownictwa i Architektury Politechniki Szczecińskiej: 219-230.

Wiśniewski B., 1997. Zmienność zapasu wody pod stępką statku w czasie wezbrań sztormowych (Sum.: Variability of water reserves under a ship's keel during storm surges). Inżynieria Morska i Geotechnika 5: 325-327.

Wiśniewski B., 2005a. Bezpieczeństwo żeglugi w portach przy ekstremalnych poziomach wód $\mathrm{w}$ morzu (Sum,: The safety of shipping in ports at extreme sea levels). Regionalne Problemy Ochrony Środowiska w Zjednoczonej Europie, XIII Seminarium Naukowe, Szczecin-Norymberga.

Wiśniewski B., 2005b. Contribution of long-term tide components to sea level variations. Oceanological and Hydrobiological Studies 34(2): 5-14.

Wiśniewski B., Holec M., 1983. Zarys Oceanografii, Dynamika Morza, cz. 2, Wydawnictwo Wyższej Szkoły Marynarki Wojennej, Gdynia.

Wiśniewski B., Kowalewska-Kalkowska H., 2007. Water level fluctuations in the Odra River mouth area in relation to passages of deep low-pressure systems. Oceanological and Hydrobiological Studies 36 (1): 69-82.

Wiśniewski B., Wolski T., 2009. Katalogi wezbrań i obniżeń sztormowych poziomów morza oraz ekstremalne poziomy wód na polskim wybrzeżu (Sum.: Catalogues of storm-generated sea level surges and falls and extreme water levels on the Polish coast ).Wydawnictwo Akademii Morskiej, Szczecin.

Wiśniewski B., Wolski T., 2011. A long-term trend, fluctuations and probability of the sea level at the southern Baltic coast. Journal of Coastal Research Special Issue 64. ICS2011 (Proceedings) Poland: 255-259. 